\title{
INDUSTRY DYNAMICS IN THE GERMAN MERGER AND ACQUISITIONS MARKET
}

\author{
ANDRÉS RODRÍGUEZ-POSE* \& HANS-MARTIN ZADEMACH** \\ *Department of Geography and Environment, London School of Economics, Houghton Street, London WC2 \\ 2AE, UK. E-mail: a.rodriguez-pose@lse.ac.uk \\ **Institute of Economic Geography, University of Munich, Ludwigstr. 28, 80539 Munich, Germany. \\ E-mail: zademach@bwl.uni-muenchen.de
}

Received: November 2004; revised December 2005

\begin{abstract}
The recent wave of mergers and acquisitions (M\&As) is not only profoundly altering the structure of businesses, but has also triggered a thorough reshuffling in the location of economic decisionmaking. This paper explores these changes in Germany over the last decade, with particular attention being paid to industry-specific transformations. In order to identify the logic behind changes in the location of economic decision-making, four factors are analysed across ten different industrial sectors. These determinants include the presence of economies of proximity and agglomeration, the degree of metropolitan interconnectivity (or 'archipelago economies'), the concentration of economic decision-making in large urban metropolitan areas, and the role played by geographical distance in shaping M\&As. The results indicate that different industries display significantly different spatial merging behaviours, with economies of proximity, concentration and agglomeration playing a capital, but different role in determining the dynamics of M\&As across sectors in Germany. There is also - with the exception of the media industry, as well as information and communication technologies - little sign of geography losing importance in economic transactions.
\end{abstract}

Key words: Mergers and acquisitions, industry sectors, gravity model, agglomeration, distance, Germany

\section{INTRODUCTION}

Since the mid-1980s most of Europe and the developed world experienced an unprecedented wave of mergers and acquisitions (M\&As) that only faded away during the economic downturn at the beginning of the twenty first century. In 2000 the global market for M\&As represented US\$ 3,498 billion ${ }^{1}$ (UN 2002). Germany, together with the US and the UK, was one of the three most important markets for M\&As (Economic Intelligence Unit 1996; OECD 2000). During the 1990 s alone, around 30,000 corporate takeovers involved at least one German firm.

This massive number of takeovers ${ }^{2}$ has led to important changes not just in the structure of businesses, but also to a thorough reshuffling in the location of economic decision-making. In Germany and elsewhere, M\&As have contributed to an increasing concentration of corporate control in core regions and urban agglomerations and to the reinforcement of existing headquarter locations as major economic control nodes (O'hUhallachàin 1994; Chapman \& Edmond 2000; see also Duranton \& Puga 2003). Yet whereas research on corporate takeovers from a microeconomic perspective is extensive, the number of empirical studies examining its overall effects on the location of economic decision-making is still relatively small. In particular, the relevance of place-specific attributes in M\&A decisions remains a deeply neglected topic in geographical research (Green \& Mayer 1997). 
This paper builds on Rodríguez-Pose \& Zademach's (2003) exploration of the impact of the wave of M\&As in the 1990s on the changing geography of economic decision-making in Germany. Its aim is to deepen our understanding of the role played by location factors in M\&A activity, paying particular attention to a dynamic examination of the changes in the spatial distribution of M\&As across ten German industrial sectors, which range from knowledgeintensive industries such as financial services, media, or information and communication technologies (ICT) to more traditional sectors, such as automotive, heavy manufacturing, or the textile industry. Taking the MEFA Review Database of the German Handelsblatt group as the source of data, we examine German M\&As during the 1990s in order to identify different types of processes and their spatial impact across sectors. We first focus on the possible existence and significance of local clustering processes, i.e. economies of proximity and agglomeration, and the degree of metropolitan interconnectivity (or 'archipelago economies'). Second, the gravitational forces of different industrial sectors are scrutinised, highlighting whether there is a tendency towards concentration of economic decisionmaking in large agglomerations. Finally the changing role of geographical distance and its effect on M\&As is studied.

The paper is divided into four further sections. Section two reviews existing literature in order to provide some insights about the territorial impact of M\&As and to assess whether significant sectoral differences in M\&As exist. The description of the database and the methods applied are presented in section three, which also contains a brief overview of the overall territorial dynamics of the wave of M\&As in Germany. Section four examines these dynamics across ten sectors (financial services, insurance, transport, media, ICT, heavy manufacturing, automotive, energy, chemicals and textiles), which represent a mixture of knowledge-intensive and more traditional industries. Section five concludes.

\section{CORPORATE TAKEOVERS IN SPATIAL PERSPECTIVE}

As today's dominant form of foreign direct investment in developed countries, M\&As have become one of the main drivers of industrial restructuring. Firms engage in M\&A activity for several reasons. The basic strategic corporate objectives include the search for new markets, increased market power and dominance, greater size and scope, efficiency gains through synergies, and geographic and product line diversification, i.e. the spreading of risk. Corporate takeovers enable firms to quickly access strategic assets, such as skilled labour, patents, brands, licenses, or management skills (e.g. Porter 1990; Trautwein 1990; Berkovitch \& Narayanan 1993; Dunning 1997). Further central factors motivating firms to undertake M\&As are financial enticements - such as tax treatment and subsidies, transfer pricing, trade barriers, transportation costs, or monopoly type practices (Ravenscraft \& Scherer 1987; Healy et al. 1992; Loughran \& Vij 1997; compare also Clark 1993; Wrigley 1999) - and personal or behavioural attributes (Shleifer \& Vishny 1989; Avery et al. 1998; Shinn 1999).

Corporate takeovers and mergers are significant stimuli for firm restructuring and economic change (see Curry \& George 1983; Jensen \& Ruback 1983; Davies \& Lyons 1996; Nilsson \& Schamp 1996). But they also have profound contextual and socio-institutional implications and are by no means an 'aspatial phenomenon': strategic decisions on the transfer of assets and control affect not only the firms involved, but also both the locations and environment with which they are associated and the organisational and geographical shape of industries as a whole. In brief, M\&As have become one of the keys in shaping the location of economic decision-making.

The spatial impact of M\&As assumes many forms. First, a number of studies have highlighted the link between M\&As and the spatial concentration of economic decision-making in core areas, with M\&As reinforcing the role of cites as locations of power and control (e.g. Rodríguez-Pose \& Zademach 2003; compare also Friedmann 1986; Sassen 1991, 2000; Castells 1996; Taylor 2000; Duranton \& Puga 2003). Second, given the aforementioned link, M\&As contribute to exacerbate territorial disparities (Chapman \& Edmond 2000) and lead to changes in urban hierarchies (Green 1990). Third, M\&As foster functional links between cities with similar roles in a world economy, overcoming distance and generating a sort of 
'archipelago economy', by which the connection between distant cities is greatly enhanced, at the expense of the relationship between a region and its hinterland (Veltz 1996, 2000).

Yet, despite their increasing importance, comprehensive comparative empirical studies addressing the spatial impact of corporate takeovers - be it at aggregate, industry, or firm level - remain scarce. 'Why [do] recent developments of enormous economic geographical impact such as ... corporate mergers receive such short shrift?' (Markusen 2003, p. 396; see also Chapman 2003). The main reason behind the relative neglect of the importance of M\&As in geographical location analyses has traditionally been limited data availability (Sachwald 1994). A great majority of the existing studies focuses explicitly on one industry or sector (e.g. Ashcroft \& Love 1993; Lagendjik 1995; Nuhn 1999a, 2004; Chapman \& Edmond 2000; Lo 2000 ), or studies a single case of a firm or M\&A transaction (e.g. Bathelt \& Griebel 2001; Nuhn 1999b, 2001; Zeller 2003; see also Green \& Mayer 1997 for a more comprehensive literature review). Though this type of research has delivered inspiring insights and empirical evidence about the motives driving M\&As and about post-merger or acquisition restructuring processes, they unfortunately offer very little insight into the role played by location attributes in takeover activity across different industrial sectors, the extent to which place-specific advantages influence merger decisions, how takeover activity affects economic decision-making, and particularly how sectoral structural characteristics relate to more general M\&A patterns.

Industry characteristics, such as sectoral growth prospects, market structure, and competition, have, however, a strong influence on corporate takeovers (OECD 2001, p. 30). This becomes manifest when the a priori distinct locational patterns of the more 'traditional' sectors (i.e. primarily mature manufacturing industries) and the globalised, information-based socio-economic formation (Martin 2002) of the so-called 'new economy' are compared. On the one hand, the less traditional knowledge-intensive sectors of the 'new economy' are characterised by dynamic markets, networked organisation forms, and digitisation as a key technological driver (Kelly 1998; Gillespie et al. 2001). Its industries are specialised in the provision of fundamentally immaterial intellectual outputs, that can be transported online virtually without costs. These sectors fundamentally depend on processes of knowledge creation, interactive learning and innovation, in which human and social capital, R\&D activity and the attraction of talent are key determinants for success. In order to survive and progress, new economy companies are often compelled to look for partners from whom such intangible assets can be obtained and absorbed.

On the other hand, more traditional manufacturing firms rely on material goods, economies of scale, exports, and physical capital as the main sources of value. The dominant technological mode of mature industrial sectors is mechanisation; job specific skills are therefore more important than broad skills, flexibility, and adaptability, and $\mathrm{R} \& \mathrm{D}$ activities are of rather low or moderate importance. Although traditional sectors increasingly use new economy technologies such as ICT, costs and availability of labour and real estate, provision of space, access to road networks, and transport infrastructure, as well as proximity to markets, are still key in their location decisions.

These very diverse forms of industrial organisation can be expected to generate different location patterns. Traditional activities, given their need for extensive spaces, would look, following a Weberian tradition, for proximity to markets, raw materials, energy and labour, with transport costs having a capital role in their ultimate location. The restructuring of these activities through M\&As is unlikely to alter their established territorial pattern. Knowledgeintensive sectors and related industries, in contrast, rely significantly on the distancetranscending capabilities of new technologies. In theory, this allows for much greater flexibility in terms of location, with economic activity capable of emerging almost anywhere. Such a 'weightless economy' (Quah 1996, 1997; Coyle 1997) and the 'death of distance' (Cairncross 1997) that, in theory, characterises these sectors can result in a much greater dispersal of economic decision-making. Many of the characteristics of the knowledge-intensive sectors point, however, in an opposite direction. According to Leamer \& Storper (2001), these sectors - while permitting a decentralisation of certain routine activities - contribute to reinforce 
urban concentration and agglomeration. Economic success in the knowledge-intensive services often hinges on the creation of networks, on social interaction, locally-based tacit knowledge, and personal contacts - factors whose genesis is significantly facilitated by geographical proximity (Rodríguez-Pose \& Storper 2006). The emergence of strong clustering effects such as the concentration of 'dot.com' start-ups or multimedia industries in major cities such as London, New York or Los Angeles is one spatial expression of the new economy (e.g. Scott 1996; Pratt 2000; Grabher 2001, 2002; Florida 2002; compare also Martin \& Sunley 2003). Many of the essential factors in these sectors are, in turn, central dimensions in M\&A activity as well. Under these circumstances, M\&As in less traditional and mature sectors could reinforce the agglomeration of economic decision-making, perpetuating core-periphery patterns.

\section{THE RESHAPING OF ECONOMIC DEGISION-MAKING IN GERMANY THROUGH M\&AS}

In this paper we assess whether the abovementioned differences across industrial sectors lead to sectoral differences in the spatial arrangements of M\&As in Germany. In order to do that, we first present the data and the methodology used in the empirical analysis, before highlighting the overall territorial dynamics of M\&As in Germany. Industry specific differences in M\&As patterns are then addressed below.

Data and methodology - The source of the empirical analysis is the $M \mathcal{E}$ A Review Database. This dataset is the most comprehensive record of recent M\&A activity in Germany. It provides information on more than 29,000 M\&As that took place in the 1990s, in which at least one German firm was involved, and classifies whenever possible - each acquisition by location, industry and type. ${ }^{3}$ Our treatment of these data follows a two step approach: The first step consists of an analysis of the different markets of M\&A across the various German sectors and focuses on a total of 19,034 intranational transactions, excluding the cases for which the dataset provides no industry-specific information. The aim of this part of the analysis is to set up a basic classification of the spatial characteristics of sector-specific takeover activities. Ten different industries are covered in the analysis, in order to allow for a comprehensive illustration of how M\&A specificities vary across sectors. These include financial services, insurance and transport industries, media, ICT, heavy manufacturing, automotive, energy, chemicals and textiles. They represent a mixture of traditional and more knowledge-intensive sectors. More than 11,000 intranational deals were conducted during the 1990s in these 10 industries alone, making them the most dynamic sectors in Germany in terms of M\&As activity ${ }^{4}$ (Mergers \& Acquisitions 2003).

In this first step a descriptive examination of the specifics of M\&As across each selected industry is conducted. Two criteria form the basis for the classification of types of M\&As according to sector: economies of proximity, measured by the number of M\&As that have been executed within the boundaries of each of the 40 German Regierungsbezirke (the administrative unit below Länder), and metropolitan interconnectivity - as an indicator of the 'archipelago economies' in Germany - estimated as the proportion of transactions undertaken only within and between the six most important German centres of corporate M\&As: Frankfurt, Düsseldorf, Hamburg, Munich, Berlin and Cologne (compare Rodríguez-Pose \& Zademach 2003).

The second step of the analysis is a multiple regression analysis that, in essence, constitutes the estimation of a gravity model. ${ }^{5}$ In logarithmic form, the model adopts the following form:

$$
\begin{aligned}
M \mathcal{E} A_{i j, t}= & \alpha+\beta_{1} \ln G D P_{i, t}+\beta_{2} \ln G D P_{j, t} \\
& -\beta_{3} \ln D i s t_{i j}+\varepsilon
\end{aligned}
$$

where the number of M\&As that took place between region $i$ (where the acquiring firm is situated) and region $j$ (locating the M\&A target) in each year of investigation $t$ (1990-99) is a function of the regional GDP in the two Regierungsbezirke involved, indicating the respective level of agglomeration, as well as the geographical distance between the acquiring firm and its target. ${ }^{6}$ The estimates of the economic effects are depicted by the correlation coefficients $\beta_{1}, \beta_{2}$ and $\beta_{3}$ respectively; finally, $\alpha$ denotes the constant and $\varepsilon$ the error term. As the regressions are conducted for every year in the database and for each of the 10 industries included in the analysis, a dynamic picture of 


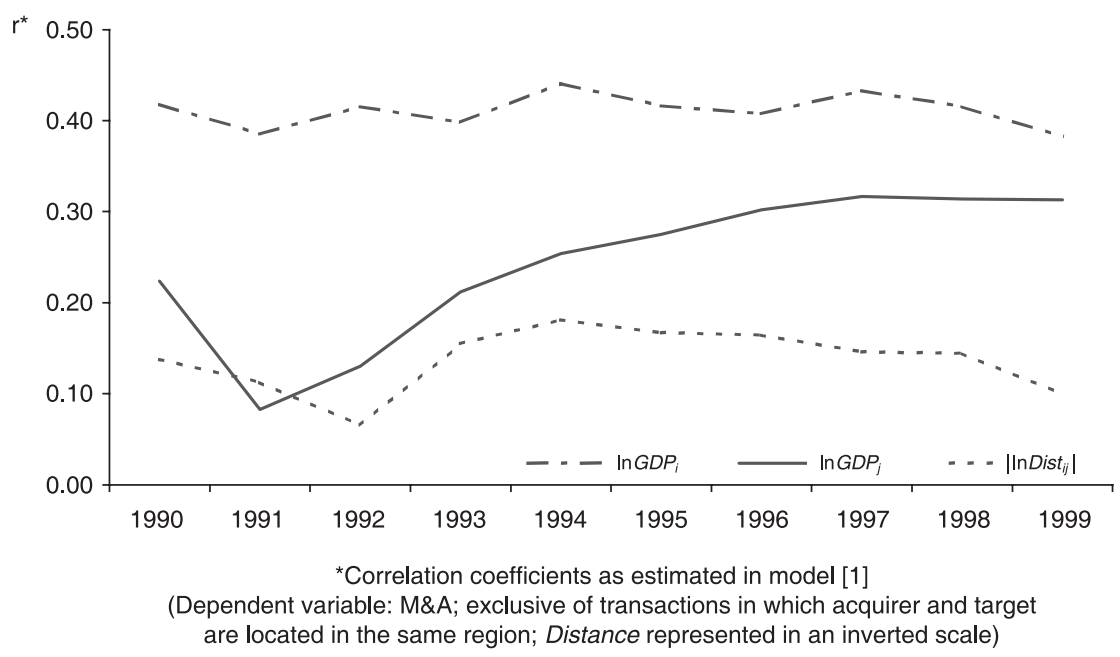

Figure 1. The changing relevance of agglomeration economies and geographical distance in the German ME $A$ economy.

the processes at work in each of the considered sectors as well as the changing role of physical distance in the geography of M\&A emerges.

Territorial dynamics of M\&As in Germany As Rodríguez-Pose \& Zademach (2003) have shown, the increasing relevance and interconnection of large metropolitan areas is an important feature of the overall German M\&A panorama. This finding is reinforced by the results of the regression analysis of Equation (1) for all 19,034 intranational M\&As conducted in Germany between 1990 and 1999. Figure 1 displays the year on year results of the standardised correlation coefficients for the independent variables included in the model ${ }^{7}$. The results highlight that whereas the early 1990s were characterised by a pronounced concentration of economic decision-making in large urban areas - i.e. the economic size of the regions where acquirers were located was typically much larger than that of the regions of target firms - the size gap diminishes considerably as the decade progresses. By 1999, although acquiring firms were still generally located in economically stronger regions, the agglomeration coefficient for target firms had become relatively similar.

Figure 1 also denotes the extent to which the role of geographical distance in German M\&As changed over time. Just after Reunification when the dominant trend was for Western companies to acquire firms in the former GDR, geographical proximity counted for little. After 1992, however, the profound restructuring in East Germany became exhausted and distance began to emerge as an important factor for the spatial distribution of M\&As: Once the economic size of the region of the acquiring and the target firm is controlled for, proximity played an important role, with firms preferring other firms situated nearby rather than far away as targets (Rodríguez-Pose \& Zademach 2003, p. 1917). The magnitude of the proximity coefficient peaked, however, in 1994 and has since then gradually been eroded - although never turning statistically insignificant. The waning importance of the distance factor contrasts with the rising size and significance of the coefficients of the regions where target firms are located; this underlines the fact that geographical proximity is increasingly being substituted by size or agglomeration as the determinant factor guiding M\&As. Hence, the overall economic geography of M\&As in Germany during the 1990 s can be regarded as the product of essentially two overlapping dimensions: whereas in the early 1990s, the general restructuring of industrial production as a consequence of Reunification was characterised by processes of intense economic concentration, in the late 1990s, a panorama of 'rising metropoli' clearly dominated. 


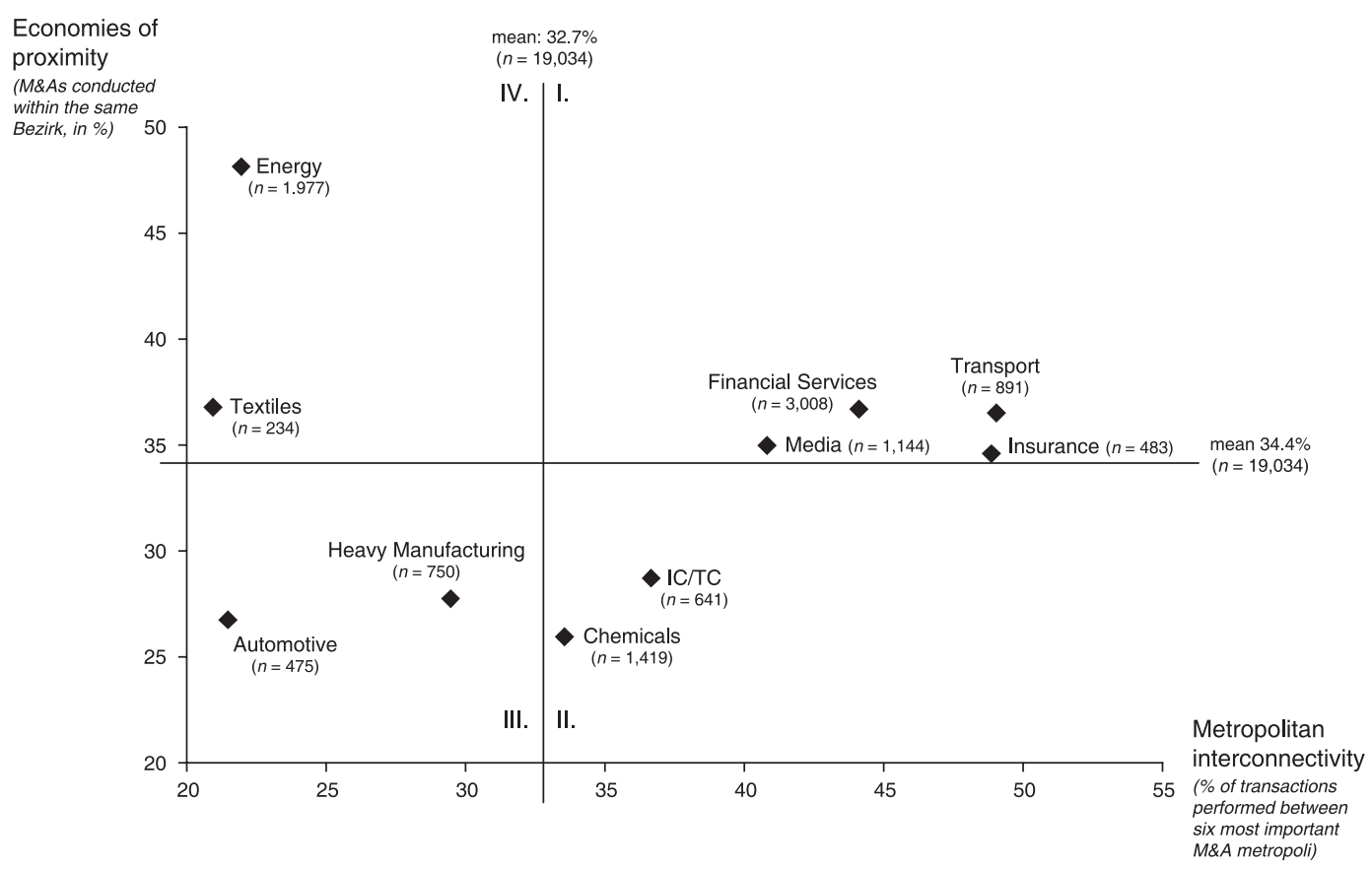

Figure 2. MẼA specificities across German industry sectors: economies of proximity vs metropolitan interconnectivity.

\section{INDUSTRY SPECIFICS IN GERMAN TAKEOVER ACTIVITY}

The question that emerges at this point is whether these general trends prevail for all sectors or whether there are - as could be expected - significant differences across industries and, more specifically, across, on the one hand, more traditional and, on the other, knowledgeintensive sectors. In the following section we address this issue by analysing the 10 sectoral markets highlighted earlier.

Classifying the markets of M\&As - Figure 2 classifies each of the 10 sectors included in the analysis according to their M\&A specific characteristics. The resulting industry clusters are determined by the role that geographical proximity plays in M\&A decisions and the degree of metropolitan interconnectivity in an industry's takeover performance.

Industrial sectors are thus allocated to four quadrants. Media, financial services, transport and insurance are all in the first quadrant, showing above average relevance of both geographical proximity and metropolitan interconnectivity. In all four industries, the share of takeovers performed within the same region is close to 35 per cent, while more than 40 per cent of transactions take place within or between the six most important German metropoli. Quadrant II comprises the chemical and ICT sectors. M\&As in these sectors are featured by above average metropolitan interconnectivity, but spatial proximity plays a smaller part than in the four industries in Quadrant I. The heavy manufacturing and automotive sectors can be found in Quadrant III, indicating below average importance of proximity and metropolitan interconnectivity. M\&As would thus have contributed to a greater relative dispersal of these activities, with respect to the concentration experienced in the majority of the other sectors. Finally, M\&As in the textile and energy sectors have - with the automotive sector - the lowest proportion of intermetropolitan takeovers, but are heavily determined by proximity (951 of 1977 M\&As in the energy sector in the 1990s took place within the same Regierungsbezirk).

The differences in the role of economies of proximity and inter-metropolitan connectivity 
detected among the 10 sectors are reinforced by the results of the gravity regression model for each sector reported in Figure 3 (and in the Appendix): Here, the importance of the role of the size of the markets of the acquiring and the acquired firm and of distance vary significantly from one sector to another. When the criteria used in Figure 2 (economies of proximity and metropolitan interconnectivity) and the variables included in the regression analysis (tendency towards concentration and relevance of distance) are combined for each sector, an extremely variegated picture emerges (Table 1).

This picture is one in which a straightforward division between the factors that drive M\&As in more traditional and knowledge-intensive sectors - or, oversimplifying, between an 'old' and a 'new' economy - is nowhere to be seen. Economies of proximity and agglomeration are important in some traditional industries, such as textiles and energy, but also in the knowledge-intensive financial service and insurance sectors, as well as the creative media industry. In ICT among the knowledge-intensive sectors, and automotive and heavy manufacturing among the more traditional ones, their role is, in contrast, almost negligible. Similarly, there is a strong tendency towards concentration in large urban areas in some of the knowledge-intensive sectors like finance and insurance, just as in several traditional industries (e.g. heavy manufacturing or energy). Distance, finally, is relevant for sectors as dissimilar as financial services and energy. Hence, more than a traditional versus knowledge-intensive or 'old' versus 'new' division of the geography of M\&As in Germany a fourfold division seems to emerge from the results presented in Table 1. The four groups may be classified as follows:

Finance and Transport - The concentration of economic decision-making in metropolitan areas as a consequence of the wave of M\&As in the 1990s was most noticeable in the German financial sector as well as the insurance and the transport industries. In almost three out of every four transactions in the transport sector, the acquiring firm had its headquarters in one of the six main German urban areas; and in finance and insurance, the share was slightly below 70 per cent. These sectors also had - with the exception of energy - the highest levels of inter-city M\&As among all examined industries (compare Figure 2). Firms in these sectors not only benefit from inter-metropolitan relations, but being located within the same urban agglomeration is an important feature of their takeover activity. Mergers such as those of Dresdner Bank in Frankfurt and the assurance company Allianz AG, Munich, or the Bavarian HypoVereinsbank, which emerged from Bayerische Hypotheken- und Wechelsbank and Bayerische Vereinsbank (both located in Munich) in 1998, may serve as examples illustrating the particular role played by economies of agglomeration and proximity in this category. In some of the cases above regulation has also played a key role in determining M\&As. German capital markets are heavily regulated at the Länder level, making geography a crucial dimension in the German model of corporate governance (Wójcik 2002, p. 1455; Clark \& Wójcik 2005).

This pattern reflects the archetypical behaviour of the so-called 'progressive' services firms which depend first of all on accessibility and proximity to each other. These firms benefit from access to large markets, a vast range of other local business activities, and from large pools of qualified labour and educational achievements in urban areas. Readily accessible transport facilities, a competitive market environment, as well as availability of high-quality telecommunications infrastructure and quality office accommodation are further location attributes of relevance in these industries. Once the fact that M\&As have led to a greater geographical concentration of these sectors in urban agglomerations is taken into account, distance also emerges as a significant factor. Especially in financial services - with more than 3,000 transactions in terms of M\&As by far the most dynamic German sector in the 1990s there is a greater chance that firms acquire a target in neighbouring rather than in far away urban areas.

Media and ICT - In contrast to what might have been expected, the wave of M\&As in the media and ICT industries does not seem to have led to a considerably greater concentration of activity. ${ }^{8}$ This is related to the fact that the great majority of the companies in these sectors tends to be small and do not benefit from significant economies of scale. Furthermore, these are the 

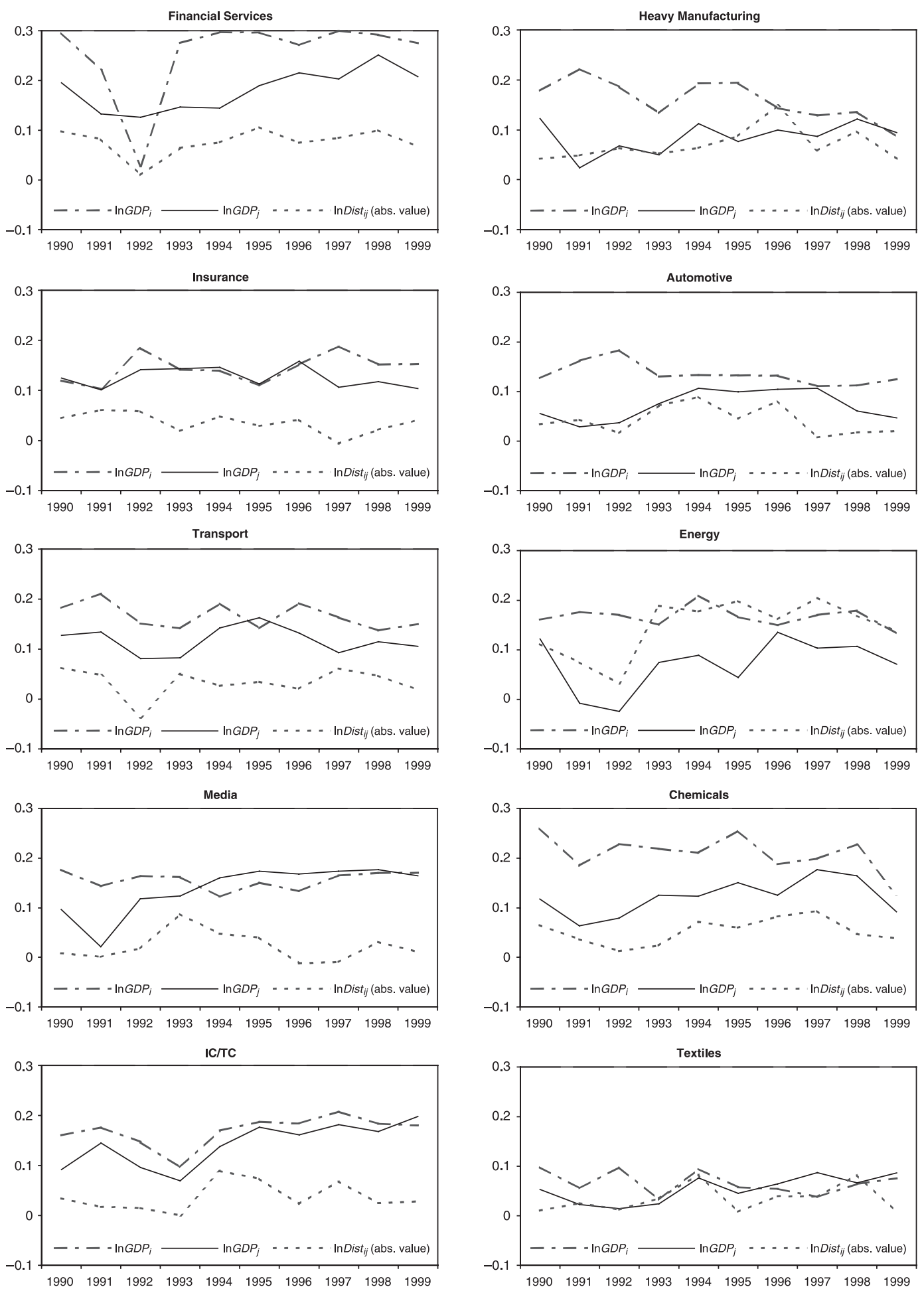

Figure 3. MESA specificities across industry sectors: results of the regression analysis. 
Table 1. The German markets of ME'A: classification of industries.

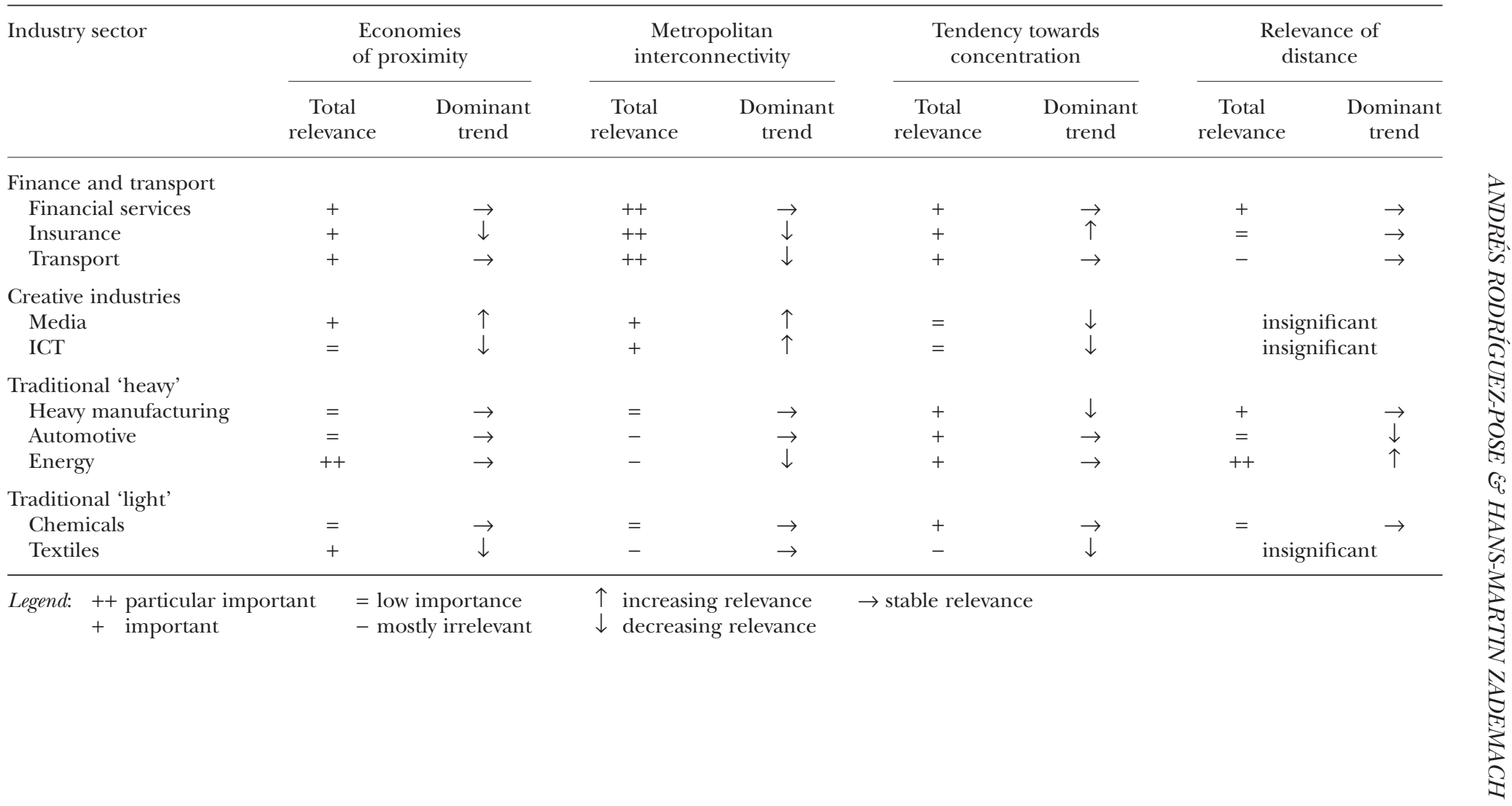


real sectors in the 'new' economy: highly mobile, increasingly relying on telecommunications networks, and, in general, less dependent on R\&D activity than other sectors, such as the automotive or the chemical sector. In fact, distance appears as an insignificant factor for corporate takeovers; that is to say that M\&A transactions at greater distances, such as the acquisition of a call centre in a rather peripheral region for instance (Graef 1998), are more likely to occur than in finance, energy or heavy manufacturing. This result points in the direction of Quah's $(1996,1997)$ notion of a weightless economy, which emphasises the radical possibilities of an almost costless reproduction and distributions of e-goods, such as software or multimedia services, and where the importance of the availability of high-quality communication facilities seems to be growing perhaps to the detriment of close personal contacts. It would thus seem that in these two sectors traded interdependencies would be gaining weight at the expense of untraded interdependencies.

This does not mean, however, that closeness and agglomeration do not matter for these sectors. Takeovers in media and ICT were also considerably affected by proximity and intermetropolitan links - although to a slightly lesser extent than in finance and transport. In both industries, the relevance of interurban connections is above average, and close to a third of all M\&As still took place within the same region. These characteristics stress the significance of social interaction, the importance of a creative environment, or handshake transactions and face-to-face communication, although these factors, in industries that make the maximum use of telecommunication technologies, may depend less on geographical distance and physical proximity than before (Glückler 2005). In sum, both traded and untraded interdependencies represent therefore significant factors shaping M\&A activity in media and ICT.

Traditional 'heavy' industries - M\&A activity in heavy manufacturing, automotives, and energy is driven first and foremost by economies of scale. The completion of the liberalisation of the German energy market in 1998 provoked extensive changes in the German energy sector (e.g. Haas \& Scharrer 1999) and the bulk of the more than 900 local, rather small energy dis- tributors was acquired by one of the then eight German Verbundsunternehmen (transmission system operators), i.e. the companies active in the high-voltage dispatch sector, like EnBW, the RWE Group or EON.Net, the latter being created from the merger of PreussenElektra-Netz and Bayernwerk Netz. Potential benefits from size and consolidation have also led to profound restructuring in automotives (e.g. Hudson \& Schamp 1995; Schamp 2000) and even more distinctively in heavy manufacturing. Though in this sector, the share of transactions conducted from the six main German centres of corporate control was a considerable 53 per cent of the total (compared to $42 \%$ and $38 \%$ in automotives and energy respectively), overall, urbanisation and economies of agglomeration affect all three sectors to a rather smaller extent in comparison to other sectors.

It also seems that geographical distance and economies of proximity are relatively minor factors in the automotive and heavy manufacturing sectors. In energy, however, proximity plays a more important role, with companies either merging in the same region or acquiring others in nearby, rather than distant, areas. This picture has to be seen against the background of the need for large plants in these mature industries (in which headquarters still tend to locate close to their plants) and most notably the costs of space in large urban agglomerations. In the case of a heavily regulated sector, like the energy industry, the 'German model' of corporate governance, with its regional dimension (Wójcik 2002), enhances the role of proximity.

In sum, the dominance of economies of scale can be seen as the major driving force behind the wave of corporate consolidation in these sectors. In particular with regard to energy and heavy manufacturing, location specifics have nonetheless proved to represent further significant factors. Proximity also influences the spatial outcomes of corporate takeovers in mature manufacturing industries.

Textiles and chemicals - Textiles and chemicals make up the last group. The German textile industry underwent a profound restructuring process and most notably a significant decline even before Reunification (e.g. Hassink 2003; Haas \& Zademach 2005). As a consequence, this sector shows by far the lowest number of 
M\&As and has to be regarded the least representative in the sample. Textile firms are mature traditional industries in which the importance of $\mathrm{R} \& \mathrm{D}$ is relatively low and design and marketing capacities are increasingly at the root of the success of firms; plant size is a dominant factor. Textile plants are very sensitive to the rising cost of space in large urban areas. Therefore the result is an industry that is less driven by urbanisation economies and much less prone to concentration. Although the importance of proximity for M\&As is slightly above average, distance becomes virtually irrelevant.

Likewise, the German chemical sector underwent an extensive restructuring in the 1990s (Bathelt 1997). Chemical industries were affected by the changing global environment, with transnational mergers becoming frequent (e.g. Zeller 2000; Bathelt \& Griebel 2001). The outcome of intra- and international restructuring in the chemical sector was a distinct geographical concentration of company headquarters. Metropolitan interconnections and proximity played, on the other hand, a relatively minor part in corporate takeovers in this sector. The overall M\&A pattern of the chemical sector thus replicates an industry which simultaneously operates in both narrow local clusters and via complex relations between subcontractors, service providers, and integrated corporate units across both the entire nation and the globe.

\section{CONCLUSIONS}

Corporate takeovers and mergers constitute a key expression of the information-based and globalised economy of the late twentieth and early twenty first centuries. They also particularly reflect the ongoing restructuring of production processes in an increasingly competitive environment. Taking the German economy as an illustrative case, this paper has analysed the dynamics of M\&As and the extent to which the most recent wave of corporate consolidation led to a profound relocation of economic decisionmaking and to an increasing concentration of corporate power and control in large urban areas. Agglomeration economies and, to a much lesser extent, geographical distance seem to have been the main factors shaping the restructuring of the territorial distribution of economic power and activities in Germany. From this perspective, M\&As represent both a symptom and a cause for the increasing concentration of economic decision-making in large urban areas and of the rise of the economic power of large metropolitan areas.

The analysis of M\&As in 10 industrial sectors has highlighted the diverse combinations of factors at play across different industries. The diverse markets of M\&As are affected by similar forces of economies of proximity, concentration and agglomeration, although in significantly different ways from one sector to another. Physical distance is another important factor, as there is relatively little sign with the exceptions of the media and ICT sectors - of geography losing importance in economic transactions. Even in some knowledgeintensive sectors, such as finance and insurance, proximity plays as important a part as ever, casting doubts on the much-publicised existence of general trends towards the emergence of a weightless economy or the end of geography. 


\section{APPENDIX: M\&A SPECIFICS ACROSS INDUSTRY SECTORS-RESULTS OF THE REGRESSION ANALYSIS}

\begin{tabular}{|c|c|c|c|c|}
\hline Depen & $\begin{array}{l}1 \& \mathrm{~A} \\
\ln G D P_{i}\end{array}$ & $\ln G D P_{j}$ & $\ln$ Dist $_{i j}$ & $\mathrm{R}^{2}$ \\
\hline \multicolumn{5}{|c|}{ a. Financial Services $(n=1,905)$} \\
\hline 1990 & 0.296 & 0.195 & -0.098 & 0.130 \\
\hline 1991 & 0.221 & 0.133 & -0.082 & 0.070 \\
\hline 1992 & $0.028^{\text {n.s. }}$ & 0.126 & $-0.010^{\text {n.s. }}$ & 0.016 \\
\hline 1993 & 0.275 & 0.146 & -0.065 & 0.098 \\
\hline 1994 & 0.297 & 0.144 & -0.076 & 0.111 \\
\hline 1995 & 0.296 & 0.190 & -0.106 & 0.128 \\
\hline 1996 & 0.271 & 0.215 & -0.075 & 0.119 \\
\hline 1997 & 0.304 & 0.203 & -0.084 & 0.134 \\
\hline 1998 & 0.292 & 0.251 & -0.100 & 0.150 \\
\hline 1999 & 0.275 & 0.208 & -0.067 & 0.118 \\
\hline \multicolumn{5}{|c|}{ b. Insurance $(n=316)$} \\
\hline 1990 & 0.120 & 0.125 & -0.045 & 0.030 \\
\hline 1991 & 0.103 & 0.101 & -0.061 & 0.023 \\
\hline 1992 & 0.184 & 0.141 & -0.058 & 0.055 \\
\hline 1993 & 0.141 & 0.143 & $-0.019^{\text {n.s. }}$ & 0.040 \\
\hline 1994 & 0.139 & 0.146 & -0.048 & 0.041 \\
\hline 1995 & 0.110 & 0.113 & $-0.029^{\text {n.s. }}$ & 0.025 \\
\hline 1996 & 0.151 & 0.158 & -0.042 & 0.047 \\
\hline 1997 & 0.188 & 0.106 & $0.006^{\text {n.s. }}$ & 0.046 \\
\hline 1998 & 0.152 & 0.118 & $-0.021^{\text {n.s. }}$ & 0.036 \\
\hline 1999 & 0.152 & 0.104 & $-0.041^{\text {n.s. }}$ & 0.034 \\
\hline \multicolumn{5}{|c|}{ c. Transport $(n=566)$} \\
\hline 1990 & 0.182 & 0.128 & $-0.062^{\text {n.s. }}$ & 0.051 \\
\hline 1991 & 0.211 & 0.134 & -0.048 & 0.063 \\
\hline 1992 & 0.151 & 0.081 & $0.036^{\text {n.s. }}$ & 0.031 \\
\hline 1993 & 0.142 & 0.082 & -0.050 & 0.028 \\
\hline 1994 & 0.192 & 0.142 & $-0.026^{\text {n.s. }}$ & 0.056 \\
\hline 1995 & 0.142 & 0.162 & $-0.035^{\text {n.s. }}$ & 0.046 \\
\hline 1996 & 0.192 & 0.132 & $-0.021^{\text {n.s. }}$ & 0.053 \\
\hline 1997 & 0.163 & 0.093 & -0.061 & 0.037 \\
\hline 1998 & 0.137 & 0.114 & -0.046 & 0.032 \\
\hline 1999 & 0.150 & 0.105 & $-0.019^{\text {n.s. }}$ & 0.033 \\
\hline \multicolumn{5}{|c|}{ d. Media $(n=744)$} \\
\hline 1990 & 0.177 & 0.096 & $-0.008^{\text {n.s. }}$ & 0.040 \\
\hline 1991 & 0.143 & $0.022^{\text {n.s. }}$ & $-0.001^{\text {n.s. }}$ & 0.021 \\
\hline 1992 & 0.164 & 0.118 & $-0.018^{\text {n.s. }}$ & 0.040 \\
\hline 1993 & 0.162 & 0.124 & -0.087 & 0.047 \\
\hline 1994 & 0.122 & 0.160 & -0.048 & 0.041 \\
\hline 1995 & 0.150 & 0.174 & $-0.040^{\text {n.s. }}$ & 0.052 \\
\hline 1996 & 0.133 & 0.168 & $0.012^{\text {n.s. }}$ & 0.045 \\
\hline 1997 & 0.165 & 0.174 & $-0.009^{\text {n.s. }}$ & 0.056 \\
\hline 1998 & 0.170 & 0.177 & $-0.031^{\text {n.s. }}$ & 0.059 \\
\hline 1999 & 0.170 & 0.164 & $-0.011^{\text {n.s. }}$ & 0.054 \\
\hline \multicolumn{5}{|c|}{ e. ICT $(n=457)$} \\
\hline 1990 & 0.160 & 0.092 & $-0.034^{\text {n.s. }}$ & 0.034 \\
\hline 1991 & 0.176 & 0.145 & $-0.017^{\text {n.s. }}$ & 0.051 \\
\hline 1992 & 0.147 & 0.096 & $-0.015^{\text {n.s. }}$ & 0.030 \\
\hline 1993 & 0.096 & 0.069 & $0.000^{\text {n.s. }}$ & 0.014 \\
\hline
\end{tabular}


Continued

Dependent variable: $\mathrm{M} \& \mathrm{~A}$ $\ln G D P$ $\ln G D P_{j}$

$\ln$ Dist $_{i j}$

$\mathrm{R}^{2}$

1994

1995

0.170

0.187

0.138

0.176

1996

0.184

0.161

0.208

0.182

1998

0.183

0.168

1999

0.180

0.198

$-0.089$

$-0.073$

0.053

0.068

f. Heavy Manufacturing $(n=542)$

$\begin{array}{ll}1990 & 0.179 \\ 1991 & 0.222 \\ 1992 & 0.186 \\ 1993 & 0.134 \\ 1994 & 0.193 \\ 1995 & 0.194 \\ 1996 & 0.144 \\ 1997 & 0.128 \\ 1998 & 0.136 \\ 1999 & 0.087\end{array}$

g. Automotive $(n=348)$

1990

1991

1992

1993

1994

1995

1996

1997

1998

1999

0.127

0.162

0.183

0.130

0.133

0.132

0.132

0.111

0.112

0.125

h. Energy ( $n=1,026)$

1990

1991

1992

1993

1994

1995

1996

1997

1998

1999
0.161

0.176

0.170

0.151

0.210

0.166

0.150

0.170

0.179

0.133

i. Chemicals $(n=1,051)$

1990

1991

1992

1993

1994

1995

1996

1997

1998

1999
0.260

0.185

0.229

0.219

0.210

0.255

0.188

0.199

0.227

0.126
0.123

$0.024^{\text {n.s. }}$

0.068

0.050

0.112

0.077

0.100

0.087

0.121

0.095

0.055

$0.029^{\text {n.s. }}$

$0.037^{\text {n.s. }}$

0.076

0.106

0.099

0.104

0.107

0.061

0.047

0.122

$-0.007^{\text {n.s. }}$

$-0.024^{\text {n.s. }}$

0.074

0.089

0.044

0.136

0.103

0.107

0.071

0.118

$0.063^{\text {n.s. }}$

0.079

0.125

0.123

0.150

0.126

0.177

0.165

0.092 $-0.023^{\text {n.s. }}$

$-0.068$

0.058

$-0.024^{\text {n.s. }}$

0.077

$-0.028^{\text {n.s. }}$

0.058
0.070

$-0.042$

0.047

$-0.049$

0.051

$-0.063$

0.042

$-0.052$

0.022

$-0.064$

$-0.088$

0.052

0.049

$\begin{array}{ll}-0.149 & 0.049\end{array}$

$-0.058$

0.026

$-0.097$

0.040

$-0.042$

0.017

$-0.034^{\text {n.s. }}$

0.020

$-0.043$

0.028

$-0.016^{\mathrm{n} . \mathrm{s}}$

0.035

$-0.072$

0.027

$-0.089$

0.035

$-0.045$

0.028

$-0.081$

0.033

$-0.008^{\mathrm{n} . \mathrm{s}}$

0.023

$-0.017^{\text {n.s. }}$

0.016

$-0.020^{\text {n.s. }}$

0.018

$-0.111$

0.051

$-0.074$

0.036

$-0.032^{\text {n.s. }}$

0.031

-0.189
-0.177

0.061

0.079

$-0.199$

0.065

$-0.162$

0.062

$-0.205$

0.076

$-0.169$

0.067

$-0.138$

0.039

$-0.065$

0.083

$-0.036^{\text {n.s. }}$

0.038

$-0.013^{\text {n.s. }}$

0.058

$-0.024^{\text {n.s. }}$

0.062

$-0.072$

0.062

$-0.060^{\text {n.s. }} \quad 0.087$

$-0.082 \quad 0.054$

$-0.094 \quad 0.075$

$-0.047 \quad 0.078$

$-0.038^{\text {n.s. }} \quad 0.025$ 


\section{Continued}

\begin{tabular}{lllll}
\hline \multicolumn{2}{c}{ Dependent variable: $\begin{array}{c}\text { M\&A } \\
\ln G D P_{i}\end{array}$} & $\ln G D P_{j}$ & $\ln$ Dist $_{i j}$ & \multicolumn{1}{c}{$\mathrm{R}^{2}$} \\
\hline j. Textiles $(n=148)$ & & & & \\
1990 & 0.098 & 0.053 & $-0.010^{\text {n.s. }}$ & 0.012 \\
1991 & 0.055 & $0.022^{\text {n.s. }}$ & $-0.025^{\text {n.s. }}$ & $0.004^{\text {n.s. }}$ \\
1992 & 0.098 & $0.014^{\text {n.s. }}$ & $-0.012^{\text {n.s. }}$ & 0.010 \\
1993 & $0.032^{\text {n.s. }}$ & $0.024^{\text {n.s. }}$ & $-0.035^{\text {n.s. }}$ & $0.003^{\text {n.s. }}$ \\
1994 & 0.094 & 0.076 & -0.083 & 0.020 \\
1995 & 0.057 & 0.045 & $-0.008^{\text {n.s. }}$ & 0.005 \\
1996 & 0.054 & 0.064 & $-0.039^{\text {n.s. }}$ & 0.008 \\
1997 & $0.038^{\text {n.s. }}$ & 0.087 & $-0.038^{\text {n.s. }}$ & 0.010 \\
1998 & 0.064 & 0.066 & -0.082 & 0.014 \\
1999 & 0.075 & 0.086 & $-0.007^{\text {n.s. }}$ & 0.013
\end{tabular}

Observations: 39 (without transactions within the same region)

Degrees of Freedom: 3, 35

Notes: all coefficients are standardized

n.s.: not significant (10\%-level)

\section{Acknowledgements}

We would like to thank Hans-Dieter Haas, Murray Low, Arnold Picot, the participants of the 66. Wissenschaftliche Jahrestagung des Verbandes der Hochschullehrer für Betriebswirtschaft e.V. in Graz, as well as the editor and anonymous referees of TESG for insightful comments on earlier drafts of this paper. Furthermore, we are grateful to Steffen Mezger who provided access to the MEA Review Database as well as to Daniel Metzler and David Hajizadeh-Alamdary for their collegiate assistance. Generous financial support from the German Research Foundation DFG (grant HA 795/8-1), the Royal Society-Wolfson Research Merit Award and the Phillip Leverhume Prize is acknowledged. The usual disclaimers apply.

\section{Notes}

1. After 2000 the volume of transactions quickly fell to US $\$ 1,753$ billion in 2001 and to US $\$ 1,230$ billion in 2002 (Thomson Financial 2003; UN 2003).

2. Acquisitions (or takeovers) indicate the purchase of a company by transferring the control of assets and operations from one firm to the other, the former becoming an affiliate of the acquirer. A merger, on the other hand, implies the combination of the assets and operations of two firms to establish a new entity whose control resides in a team from one or both of the two. As the boundaries are however fluid, M\&As are often bundled together for research purposes. In fact, acquisitions are far more common than mergers: Less than three per cent of the total number of cross-border M\&As reported in the World Investment Report were officially classified as mergers (UN 2000).

3. The database is maintained by the University of St. Gallen and can be accessed via 'Genios Wirtschaftsdatenbanken' <http://www.genios.de>. As with all data sources on M\&As (see e.g. Green \& Mayer 1997; Chapman \& Edmond 2000), there is unfortunately little information on the value of the transactions, i.e. a takeovers' economic significance, and its strategic motivations. Due to missing entries as well as for methodological reasons our study does not cover all 29,385 transactions contained in the database, of which 7,765 are transnational.

4. In total, the MESA Review Database contains 18 sectors. The remaining eight sectors are building and construction; general services; electronics and medical technology; retail; aerospace; precision engineering; food and luxury articles; and paper.

5. In human geography, gravity models evaluate or forecast the various kinds of flows of goods, people, etc. between origins and destinations (spatial interaction). In basic Newtonian form, they are expressed as follows:

$$
I_{i j}=k M_{i} M_{j} \text { Dist }_{i j}^{-\beta}
$$

(C) 2006 by the Royal Dutch Geographical Society KNAG 
where $I_{i j}$ denotes the interaction between two locations $i$ an $j, M_{i}$ and $M_{j}$ represent the 'masses' measuring the strength of $i$ and $j$ (usually the population numbers of two settlements); Dist $i_{i j}$ stands for the distance between $i$ and $j$; and $k$ and $\beta$ are constants (e.g. Robinson 1998).

6. The data for $G D P_{i}$ and $G D P_{j}$ stem from the German Statistisches Bundesamt for each year during the period of analysis $t$ (1990-99). The variable distance is linearly approximated via the spatial gravity centroids of the two regions concerned.

7. Needless to say that the cases in which the acquiring firm and the target are located in the same Regierungsbezirk were excluded from the analysis. An inclusion of these events would cause a profound overestimation of the variable distance.

8. Concerning the German media industry, it is noteworthy that - besides Hamburg, Cologne, and Munich - several important industry clusters have recently emerged in smaller agglomerations, like for instance Leipzig or Potsdam-Babelsberg (compare Krätke 2002, 2003; Bathelt \& Boggs 2003).

\section{REFERENCES}

Ashcroft, B. \& J.H. Love (1993), Takeovers, Mergers and the Regional Economy. Edinburgh: Edinburgh University Press.

Avery, C., J.A. Chevalier \& S. Schaefer (1998), Why Do Managers Undertake Acquisitions? An Analysis of Internal and External Rewards for Acquisitiveness. Journal of Law, Economics, and Organizations 14, pp. 24-43.

Bathelt, H. (1997), Chemiestandort Deutschland. Technologischer Wandel, Arbeitsteilung und Geographische Strukturen in der Chemischen Industrie (German Chemical Industry. Technological Change, the Division of Labour and Geographical Structure). Berlin: Edition Sigma-Bohn.

Bathelt, H. \& J.S. Boggs (2003), Toward a Reconceptualization of Regional Development Paths: Is Leipzig's Media Cluster a Continuation of or a Rupture with the Past? Economic Geography 79, pp. 265-293.

Bathelt, H. \& K. Griebel (2001), Die Struktur und Reorganisation der Zulieferer- und Dienstleisterbeziehungen des Industriepark Höchst (IPH) (The Structure and Reorganisation of Subcontractor and Service Providers in the H-chst Industrial Park). IWSG Working paper 02-2001,
Frankfurt am Main: Johann Wolfgang GoetheUniversität Frankfurt.

Berkovitch, E. \& M.P. Narayanan (1993), Motives for Takeovers: An Empirical Investigation. Journal of Financial and Quantitative Analysis 28, pp. 347362.

Cairncross, F. (1997), The Death of Distance. London: Orion.

Castells, M. (1996), The Information Age: Economy, Society and Culture. Vol. I: The Rise of the Network Society. Oxford: Blackwell.

Chapman, K. (2003): Cross-border Mergers/ Acquisitions: A Review and Research Agenda. Journal of Economic Geography 3, pp. 309-334.

Chapman, K. \& H. Edmond (2000), Mergers/ Acquisitions and Restructuring in the EU Chemical Industry: Patterns and Implications. Regional Studies 34, pp. $753-767$.

Clark, G.L. (1993), Costs and Prices, Corporate Competitive Strategies and Regions. Environment and Planning A 25, pp. 5-26.

Clark, G.L. \& D. Wójcik (2005), Path Dependence and Financial Markets: The Economic Geography of the German Model. Environment and Planning A 37, pp. 1769-1791.

Coyle, D. (1997), The Weightless World. Strategies for Managing the Digital Economy. London: Capstone.

Curry, B. \& K. George (1983), Industrial Concentration: A survey. Journal of Industrial Economics 31, pp. 203-255.

Davies, S. \& B. Lyons (1996), Industrial Organisation in the European Union: Structure, Strategy and the Competitive Mechanism. Oxford: Clarendon.

Dunning, J.H. (1997), The European Internal Market Programme and Inbound Foreign Direct Investment. Journal of Common Market Studies 35, pp. 189-223.

Duranton, G. \& D. Puga (2003), Micro-foundations of Urban Agglomeration Economies. NBER Working paper 9931, Cambridge, MA.

Economic InTELligence Unit. (1996), International Mergers and Acquisitions. New York: Economic Intelligence Unit.

Florida, R. (2002), The Rise of the Creative Class and How It's Transforming Work, Leisure, Community and Everyday Life. New York: Perseus.

Friedmann, J. (1986), The World City Hypothesis. Development and Change 4, pp. 12-50.

Gerke, W., H. Garz \& M. Oerke (1995), Die Bewertung von Unternehmensübernahmen auf dem Deutschen Aktienmarkt (The Evaluation of Corporate Acquisitions on the German Stock 
Market). Zeitschrift für Betriebswirtschaftliche Forschung 47, pp. 805-820.

Gillespie, A., R. Richardson \& J. Cornford (2001), Regional Development and the New Economy. European Investment Bank Papers 6, pp. 109-131.

GLÜCKLER, J. (2005), Making Embeddedness Work: Social Practice Institutions in Foreign Consulting Markets. Environment and Planning A 37, pp. 17271750 .

Grabher, G. (2001), Ecologies of Creativity: The Village, the Group, and the Heterarchic Organisation of the British Advertising Industry. Environment Ẽ Planning A 33, pp. 351-374.

Grabher, G. (2002), The Project Ecology of Advertising: Talents, Tasks, and Teams. Regional Studies 36, pp. $245-62$.

Graef, P. (1998), Cyberspace and Call Centers. New Patterns of Location, Outsourcing and Reengineering of Services in Germany. Netcom 12, pp. 397-402.

Green, M.B. (1990), Mergers and Acquisitions: Geographical and Spatial Perspectives. London and New York: Routledge.

Green, M.B. \& S.P. MAYER (1997), International Acquisitions: Host and Home Country Explanatory Characteristics. Geografiska Annaler 79B, pp. 97-111.

HaAs, H.-D. \& J. Scharrer (1999), Die Deutsche Energiewirtschaft (The German Energy Sector). In: Institut FÜR LÄNDERKUNDE, ed., Nationalatlas Bundesrepublik Deutschland: Band 1. Gesellschaft und Staat, pp. 118-121. Heidelberg: Spektrum.

HAAs, H.-D. \& H.-M. ZADEMACH (2005), Internationalisierung im Textil- und Bekleidungsgewerbe. (Internationalisation and Trade in the Textile and Apparel Industry) Geographische Rundschau 57, pp. 30-38.

Hassink, R. (2003), 'Quiet' Restructuring in the Ordinary Region. A Case Study of the Textile Industry Cluster in Westmünsterland, Germany. Paper presented at the RGS-IBG International Annual Conference, London.

Healy, P.M., K.G. Palepu \& R.S. Ruback (1992), Does Corporate Performance Improve after Mergers? Journal of Financial Economics 31, pp. 135-175.

Hudson, R. \& E.W. Schamp (1995), Towards a New Map of Automobile Manufacturing in Europe? New Production Concepts and Spatial Restructuring. Berlin: Springer.

Jensen, M.C. \& R.S. Ruback (1983), The Market for Corporate Control. The Scientific Evidence. Journal of Financial Economics 11, pp. 5-50.

Kelly, K. (1998), New Rules for the New Economy. London: Fourth Estate.
KRÄTKe, S. (2002), Network Analysis of Production Clusters: The Potsdam/Babelsberg Film Industry as an Example. European Planning Studies 10, pp. 27-54.

KrÄTke, S. (2003), Global Media Cities in a Worldwide Urban Network. European Planning Studies 11, pp. $605-628$.

LagendiJk, A. (1995), The Foreign Takeover of the Spanish Automobile Industry: A Growth Analysis of Internationalisation. Regional Studies 29, pp. 381393.

Leamer, E. \& M. Storper (2001), The Economic Geography of the Internet Age. Journal of International Business Studies 32, pp. 641-665.

Lo, V. (2000), Netzwerke im Mergers \& AcquisitionsGeschäft (Networking for Localised Knowledge The Case of the M\&A-sector). In: E.W. Schamp, ed., Vernetzung als Wettbewerbsfaktor. Frankfurt am Main: Johann Wolfgang Goethe-Universität.

Loughran, T. \& A.M. ViJ (1997), Do Long-Term Shareholders Benefit from Corporate Aquisitions? Journal of Finance 52, pp. 1765-1790.

Markusen, A. (2003), An Actor-centered Approach to Economic Geographic Change. Annals of the Japan Association of Economic Geographers 49, pp. 395408.

Martin, R. (2002), From the Old Economy to the New Economy. Myths, Realities and Geographies. Paper presented at the Regional Studies Association Conference on Geographies of the New Economy, London.

Martin, R.L. \& P. Sunley (2003), Deconstructing Clusters: Chaotic Concept or Policy Panacea? Journal of Economic Geography 3, pp. 5-35.

Maskell, P. \& A. Malmberg (1999), Localised Learning and Industrial Competitiveness. Cambridge Journal of Economics 23, pp. 167-185.

Mergers \& Acquisitions. (2003), Mergers \& Acquisitions in Fakten und Zahlen (Facts and Figures on Mergers \& Acquisitions). Available online at <www.m-and-a.de>, accessed 18 September.

Nilsson, J.E. \& E.W. Schamp (1996), Restructuring of the European Production System: Processes and Consequences. European Urban and Regional Studies 3, pp. 121-132.

NuHn, H. (1999a), Konzentrationsprozesse in der Milchwirtschaft Norddeutschlands - Wirtschaftsräumliche Grundlagen und Auswirkungen (Concentration Processes in Diary Farming in Northern Germany - Spatio-economical Fundamentals and Implications). Berichte zur Deutschen Landeskunde 73, pp. 165-190. 
Nuhn, H. (1999b), Fusionsfieber - Neuorganisation der Produktion in Zeiten der Globalisierung (Merger-mania - Reorganisation of Production in Times of Globalisation). Geographie und Schule 21, pp. 16-22.

NuHn, H. (2001), Megafusionen. Neuorganisation großer Unternehmen im Rahmen der Globalisierung (Mega-mergers. Reorganisation of Big Firms in the Context of Globalisation). Geographische Rundschau 35, pp. 16-24.

Nuhn, H. (2004), Konzentrationsprozesse in der Wirtschaft (Concentration Processes in the Economy). In: InstituT FÜR LÄNDERKunde, ed., Nationalatlas Bundesrepublik Deutschland: Band 9. Unternehmen und Märkte, pp. 54-55. Heidelberg: Spektrum.

O'HUhallachàIn, B. (1994), Foreign Banking in the American Urban System of Financial Organization. Economic Geography 70, pp. 206-228.

Organisation FOR ECONOMIC CO-OPERATION AND Development (OECD). (2000), Cross-Border Mergers and Acquisitions: Their Role in Industrial Globalisation. STI Working paper 2000/1, Paris: OECD.

Porter, M.E. (1990), The Competitive Advantage of Nations. New York: Free Press.

Pratt, A. (2000), New Media, the New Economy and New Spaces. Geoforum 31, pp. 425-436.

QuAH, D.T. (1996), The Invisible Hand and the Weightless Economy. Occasional paper No. 12, Centre for Economic Performance, London: LSE. QUAH, D.T. (1997), Increasingly Weightless Economies. Bank of England Quarterly Bulletin 2, pp. 49-56.

Ravenscraft, D. \& F. Scherer (1987), Mergers, Sell-offs and Economic Efficiency. Washington, DC: Brookings Institution.

Robinson, G.M. (1998), Methods and Techniques in Human Geography. Chichester: John Wiley.

Rodrìguez-Pose, A. \& M. Storper (2006), Better Rules or Stronger Communities? On the Social Foundations of Institutional Change and its Economic Effects. Economic Geography 82, pp. 1-25.

Rodrìguez-Pose, A. \& H.-M. ZAdemach (2003), Rising Metropoli: The Geography of Mergers and Acquisitions in Germany. Urban Studies 40, pp. 1895-1923.

SACHWALD, F. (1994), European Integration and Competitiveness. Aldershot: Edward Elgar.

SAssen, S. (1991), The Global City: New York, London, Tokyo. Princeton: Princeton University Press.

Sassen, S. (2000), Cities in a World Economy. London: Pine Forge Press.
Sснамт, E.W. (2000), Vernetzte Produktion. Industriegeographie aus institutioneller Perspektive (Network Production. Industrial Geography in Institutional Perspective). Darmstadt: Wissenschaftliche Buchgesellschaft.

Scotт, A.J. (1996), The Craft, Fashion, and Cultural Product Industries of Los Angeles: Competitive Dynamics and Policy Dilemmas in a Dultisectoral Image-producing Complex. Annals of the American Association of Geographers 86, pp. 306-323.

Shinn, E.W. (1999), Returns to Acquiring Firms: The Role of Managerial Ownership, Managerial Wealth, and Outside Owners. Journal of Economics and Finance 23, pp. 78-89.

Shleifer, A. \& R.W. Vishny (1989), Management Entrenchment: The Case of Manager-Specific Investments. Journal of Financial Economics 25, pp. 123-139.

TAYlor, P.J. (2000), World Cities and Territorial States under Conditions of Contemporary Globalization, Political Geography 19, pp. 5-32.

Thomson Financial (2003), Mergers \& Acqusitions Report. Available online at <www.-mareport.com $>$. Accessed 3 September

Trautwein, F. (1990), Merger Motives and Merger Prescription. Strategic Management Journal 11, pp. $283-295$.

United NATions (UN) (2000), World Investment Report 2000. Cross-border Mergers and Acquisitions and Development. New York and Geneva: UN.

United Nations (UN) (2002), World Investment Report 2002. Transnational Corporations and Export Competitiveness. New York and Geneva: UN.

United Nations (UN) (2003), World Investment Report 2003. FDI Policies for Development: National and International Perspectives. New York and Geneva: UN.

United Nations Conference on Trade And Development (UNCTAD) (2000), Survival in Global Business Arena in Key Driver of Crossborder Mergers and Acquisitions Boom. Press release TAD/INF/2855. Available online at $<$ http://r0.unctad.org/en/press/pr2855en.htm>. Accessed 3 September 2003.

Veltz, P. (1996), Mondialisation, Villes et Territoires: L'économie d'archipel (Mondialisation, Cities and Territories: The Archipelago Economy). Paris: Presses Universitaires de France.

Veltz, P. (2000), European Cities in the World Economy. In: A. Bagnasco \& P. LE Galès, eds., Cities in Contemporary Europe, pp. 33-47. Cambridge: Cambridge University Press.

WóJcik, D. (2002), The Länder are the Building 
Blocks of the German Capital Market. Regional Studies 36, pp. 877-895.

Wrigley, N. (1999), Corporate Finance, Leveraged Restructuring and the Economic Landscape: The LBO wave in US Food Retailing. In: R. MARTIN, ed., Money and the Space Economy, pp. 185-205. Chichester: John Wiley.
Zeller, C. (2000), Rescaling Power Relations between Trade Unions and Corporate Management in a Globalising Pharmaceutical Industry: The Case of the Acquisition of Boehringer Mannheim by Hoffman-La Roche. Environment and Planning A 32, pp. $1545-1567$. 